\title{
DETERMINAN EFEKTIVITAS \\ PENERAPAN SISTEM AKUNTABILITAS \\ KINERJA INSTANSI PEMERINTAH (SAKIP)
}

\author{
Ismi Febiani, Gugus Irianto, Lilik Purwanti \\ Fakultas Ekonomi dan Bisnis Universitas Brawijaya \\ Jalan Veteran, Malang, Jawa Timur 65145, Indonesia.
}

\begin{abstract}
$A B S T R A C T$
The purpose of this study is done to determine the level of work units, central government support, guidance SAKIP evaluation of implementation, and quality and quantity of human resources of the effectiveness of the implementation of SAKIP. This research is quantitative research, collected by survey through questionnaires. The sample consisted of employees amounted by 110 respondents. This study sampling technique using non-probability sampling with saturated samples (sampling census). The results showed that the working unit commitment and the quality and quantity of human resources affect the effectiveness of SAKIP, while the central government support and evaluation guidelines on the implementation SAKIP have no influence on the effectiveness of SAKIP.
\end{abstract}

Keywords: Effectiveness SAKIP Implementation, Government Agencies Performance Account ability System, Employees

\section{PENDAHULUAN}

Adanya euforia reformasi dan terbukanya informasi mengenai program-program pemerintah di era reformasi menimbulkan banyak kesempatan bagi publik untuk mengetahui, mengikuti, menilai, serta mengkritisi program-program pemerintah. Pemerintah dituntut untuk memperbaiki tata kelolanya, untuk menerapkan konsep pengelolaan yang baik (good governance) sesuai dengan TAP MPR RI No. XI 1998. Instansi pemerintah Indonesia harus bertanggung jawab dalam menjalankan tugas pokok dan fungsinya kepada publik, sebagai bentuk tanggung jawab pemenuhan tuntutan publik atas akuntabilitas kinerja pemerintah menerapkan Sistem Akuntabilitas Kinerja Instansi Pemerintah (SAKIP).

Perkembangan akuntabilitas publik di Indonesia ditandai dengan Instruksi Presiden No. 7 Tahun 1999 tentang Akuntabilitas Kinerja Instansi Pemerintah (AKIP), yang kemudian diganti dengan Peraturan Presiden No. 29 Tahun 2014 tentang Sistem Akuntabilitas Kinerja Instansi Pemerintah (SAKIP). Peraturan Presiden No. 29 Tahun 2014 pasal 2 menyatakan bahwa SAKIP merupakan suatu sistem untuk membantu penyusunan Laporan Akuntabilitas Kinerja Instansi Pemerintah (LAKIP). Selanjutnya, pemerintah menerbitkan Peraturan Menteri Pendayagunaan Aparatur Negara dan Reformasi Birokrasi No. 12 Tahun 2015 tentang Pedoman Evaluasi atas Implementasi Sistem Akuntabilitas Kinerja Instansi Pemerintah sebagai aturan pelaksanaan SAKIP.

Beberapa fenomena permasalahan yang timbul dengan diterapkannya SAKIP antara lain terdapat paradigma yang keliru dari aparatur sipil negara bahwa keberhasilan dan kegagalan dari program dan kegiatan yang dilaksanakan semata-mata hanya untuk memenuhi penyerapan dari anggaran yang sudah dialokasikan pada instansi pemerintah pada periode tertentu, sehingga masih ditemui program dan kegiatan yang hanya menghasilkan beberapa keluaran (output)

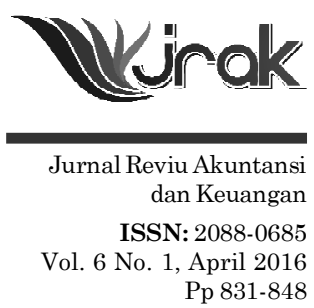


Determinan Efektivitas Penerapan...

832 namun keluaran (output) tersebut tidak berkaitan dengan pencapaian hasil kinerja program (outcome). Tujuan dari penerapan SAKIP ini agar hasil (outcome) dari pelaksanaan suatu kegiatan yang merupakan wujud dari program pemerintah memiliki kontribusi secara langsung terhadap pencapaian sasaran program yang telah ditetapkan. Dalam Peraturan Presiden No. 29 Tahun 2014 tentang SAKIP, rencana strategis (renstra) merupakan langkah awal yang harus dilakukan oleh instansi pemerintah agar dapat menjawab setiap tuntutan baik dari lingkungan strategis lokal, nasional maupun global, dan menjaga agar pelaksanaan atas rencana strategis tetap berada dalam tatanan Sistem Administrasi Negara Kesatuan Republik Indonesia. Ditetapkannya renstra yang jelas, diharapkan renstra dapat mendukung visi, misi, dan peluang serta memitigasi kendala yang akan dihadapi dalam upaya peningkatan akuntabilitas kinerja instansi pemerintah.

Terdapat faktor-faktor yang menentukan mengenai efektivitas, yang pertama menurut Penelitian Yang dan Hsieh (2007) yang berjudul "Perspective of Performance and Accountability in Public Administration, Managerial Effectiveness of Government Performance: Testing a Middle-Range Model," dan penelitian dari Ugboro (2006) yang berjudul "Effective Strategic Planning in Public Transit System," yang menyimpulkan bahwa rencana strategis tidak hanya kata-kata belaka namun perlu dikonsolidasikan ke seluruh rencana sistem dan harus mengarah pada pencapaian kinerja, untuk merealisasikan semuanya maka diperlukan dukungan dari manajemen puncak dan seluruh pegawai dengan memahami prosedur yang terdapat dalam rencana startegis. Terdapat faktor-faktor yang menentukan mengenai efektivitas yang diadopsi dari pendekatan middle range model Yang and Hsieh (2007), yaitu: dukungan politik, partisipasi stakeholder, dukungan organisasi, dan pelatihan. Dalam penelitian Nusantoro dan Subiyantoro (2009) disebutkan bahwa efektivitas penerapan SAKIP dipengaruhi oleh pedoman LAKIP, komitmen pemerintah daerah, dan dukungan pemerintah pusat. Hal ini menjadi dasar pengajuan rumusan masalah, penyusunan hipotesis, dan rancangan instrumen pada kuesioner dalam penelitian ini.

Berdasarkan model tersebut dan disesuaikannya dengan komponenkomponen yang berada dalam LAKIP, maka penelitian ini menggunakan faktorfaktor penentu yang memiliki kontribusi pada efektivitas penerapan SAKIP, yaitu: 1) komitmen satuan kerja, 2) dukungan dari pemerintah pusat, 3) pedoman evaluasi atas implementasi SAKIP, dan 4) kualitas dan kuantitas sumber daya manusia. Keempat faktor penentu tersebut akan menilai apakah SAKIP akan berkontribusi untuk meningkatkan kinerja instansi pemerintah atas pelaksanaan program dan kegiatan yang dibiayai oleh Anggaran Pendapatan dan Belanja Negara (APBN) yang disusun dan dilaporkan dalam laporan kinerja berupa LAKIP. LAKIP merupakan produk akhir dari SAKIP.

SAKIP merupakan salah satu sistem yang dibuat pemerintah untuk mendukung terwujudnya good governance. Penerapan SAKIP yang efektif, menunjukkan bahwa usaha pemerintah dalam mewujudkan good governance berjalan dengan baik. Good governance ditandai dengan meningkatnya akuntabilitas kinerja, transparansi atas penyerapan anggaran dan laporan program serta kegiatan pemerintah yang bersih dari korupsi, kolusi dan nepotisme. Ada sembilan karakteristik good governance menurut United Nations Development Program (UNDP) yang salah satunya adalah accountability (akuntabilitas). Dalam Acuan Umum Penerapan good governance pada Sektor Publik oleh Lembaga Administrasi Negara Republik Indonesia (2005) akuntabilitas termasuk dari tujuh asas penerapan good governance. Penekanan utama dari akuntabilitas publik adalah pemberian informasi kepada publik dan konstituen lainnya yang menjadi pemangku kepentingan (stakeholder). Akuntabilitas publik juga terkait dengan kewajiban untuk menjelaskan dan menjawab pertanyaan mengenai apa yang telah, sedang, dan direncanakan oleh organisasi sektor publik lakukan (Mahmudi, 2005: 9). Bila dikaitkan dengan kinerja pemerintah, menurut Mahsun (2006:25) kinerja memberikan gambaran mengenai tingkat pencapaian pelaksanaan suatu 
program/ kegiatan/ kebijaksanaan dalam mewujudkan sasaran, tujuan, visi, dan misi suatu organisasi yang berada dalam rencana strategis.

Penelitian ini dimotivasi dari berita CPNS dan Aparat pemerintah (9/12/2014), mengenai 500 kabupaten/ kota di Indonesia yang menyerahkan LAKIP pada tahun 2013, nilai tertinggi yang diraih hanya 11 kabupaten/ kota dengan peringkat B (Baik). Pemerintah kabupaten/ kota yang mendapatkan peringkat B (Baik) dengan skor 65-75 adalah Kabupaten Bintan, Karimun, Kota Tanjungpinang, Muara Enim, Kota Sukabumi, Bantul, Kabupaten Kulon Progo, Kota Yogyakarta, Sleman, Kota Manado, dan Bandung (Indonesian Companies News, 09/12/2014). Mulai 2015, penilaian LAKIP akan menjadi dasar penentuan besaran anggaran yang akan dialokasi khusus kabupaten/ kota (Indonesian Companies News, 09/12/2014). Berdasarkan penilaian laporan evaluasi kinerja tahun 2015 Kementerian Pendayagunaan Aparatur Negara dan Reformasi Birokrasi, Provinsi Kepulauan Riau secara keseluruhan menempati peringkat 10 (sepuluh) besar di Indonesia dengan predikat B (Baik) (Sumber: Berita terkini Kementerian PAN dan RB, 15/ 12/2015).

Berdasarkan latar belakang, maka peneliti ingin mengetahui faktor-faktor yang menentukan terhadap efektivitas penerapan SAKIP. Penelitian ini dilakukan pada Satuan Kerja Perencanaan dan Pengendalian Program Infrastruktur Permukiman Provinsi Kepulauan Riau atau yang disingkat dengan Satker Randal, Satker Randal merupakan Satker yang bertugas sebagai koordinator satker dibawah Direktorat Jenderal Cipta Karya Kementerian Pekerjaan Umum wilayah Provinsi Kepulauan Riau. Pekerjaan Umum mewakili lingkungan yang mayoritas masalah kerekayasaan sangat mudah untuk disusun dalam perencanaan kinerja secara terukur (Dyson dan Foster, 1982; Ugboro, 2006; dan Tapinos, Dyson dan Meadows, 2005 dalam Nusantoro dan Subiyantoro, 2009).

\section{Rerangka Konsep Penelitian}

Rerangka konsep di bawah ini dibuat berdasarkan ingin membuktikan secara empiris terhadap faktor-faktor yang menentukan efektivitas penerapan SAKIP.

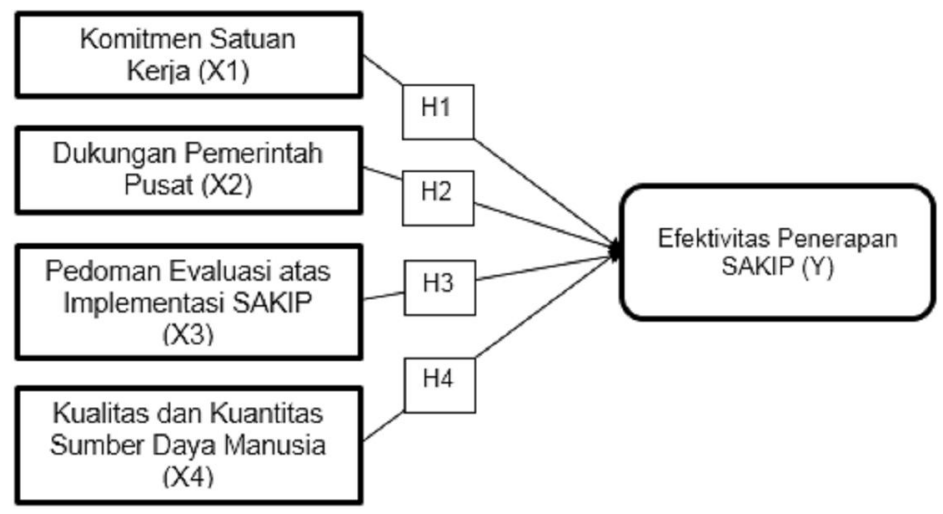

\section{HIPOTESIS}

Hipotesis penelitian dapat diartikan sebagai jawaban yang bersifat sementara terhadap masalah penelitian, sampai terbukti melalui data yang terkumpul dan harus diuji secara empiris. Pada sub bab berikut diuraikan rumusan hipotesis.

\section{Komitmen Satuan Kerja Terhadap Efektivitas Penerapan SAKIP}

Penelitian Mowday (1979) dalam Kusuma (2013) menyatakan bahwa komitmen organisasi menunjukkan dukungan yang cukup kuat terhadap nilai dan sasaran organisasi yang ingin dicapai. Komitmen Satuan Kerja, merupakan hal
Gambar 1. 
Determinan Efektivitas Penerapan...

834

yang penting dalam menerapkan penerapan suatu sistem dalam suatu organisasi. Perlu adanya komitmen, yang merupakan keinginan dari setiap Satuan Kerja untuk melakukan perubahan sesuai dengan adanya sistem yang diberlakukan demi tercapainya tujuan organisasi, koordinasi yang akan menciptakan antara pemimpin dan staf atau bawahan saling bekerja sama dalam pencapaian visi dan misi yang sama demi tercapainya tujuan organisasi, dan diperlukannya pelatihan dengan diadakannya pelatihan untuk pegawai akan menambah pengetahuan mengenai SAKIP yang sudah seharusnya diterapkan baik di tingkat pemerintah pusat maupun pemerintah daerah. Pelatihan mempunyai peran yang sangat penting karena dengan pengetahuan yang diperoleh dari pelatihan dalam proporsi tertentu diharapkan dapat memenuhi syarat-syarat yang dituntut oleh suatu pekerjaan sehingga pekerjaan dapat diselesaikan dengan baik. Jadi, para aparat pemerintah mengetahui seberapa penting dan baiknya SAKIP untuk pencapaian kinerja instansi pemerintah dalam mendukung good governance.

Menurut Wright (1992) dalam Prihantoro (2012) menyatakan bahwa semakin tinggi komitmen seseorang terhadap tugasnya maka semakin tinggi kinerja yang akan dihasilkan. Dalam penelitian Shadur, dkk (1999) yang berjudul The Relationship Between Organizational Climate and Employee Perceptions of Involvement, yang metode analisisnya menggunakan analisis regresi, hasil penelitiannya menunjukkan bahwa komitmen organisasi berpengaruh positif terhadap persepsi keterlibatan karyawan (partisipasi pengambilan keputusan, team work, komunikasi). Jadi, komitmen satuan kerja merupakan cara yang tepat untuk mengukur sejauh mana penerapan SAKIP berjalan dengan efektif. Berdasarkan uraian di atas, maka dapat dirumuskan hipotesis sebagai berikut:

$H_{1}$ : Komitmen Satuan Kerja berpengaruh terhadap efektivitas penerapan SAKIP.

\section{Dukungan Pemerintah Pusat Terhadap Efektivitas Penerapan SAKIP}

Dukungan pemerintah pusat, dengan adanya komitmen dari pemerintah pusat dalam menerapkan SAKIP di tingkat Satuan Kerja akan mendukung good governance, dengan meningkatkan akuntabilitas kinerja instansi pemerintah yang dilihat dari hasil penyerapan anggaran, pelaporan program serta adanya kegiatan yang transparan, maka diperlukan bimbingan dari pemerintah pusat dalam penyusunan pelaporan pertanggungjawaban tersebut dengan cara diawasi dan diperiksa oleh Badan Pengawasan Keuangan dan Pembangunan (BPKP) sebagaimana tertera dalam Peraturan Menteri Pendayagunaan Aparatur Negara dan Reformasi Birokrasi Republik Indonesia No. 12 Tahun 2015. BPKP bertugas dalam urusan pemerintah di bidang pengawasan keuangan negara atau daerah dan pembangunan nasional. Dalam penelitian Nusantoro dan Subiyantoro (2009), hasil penelitian menunjukkan bahwa dukungan pemerintah pusat hasilnya secara signifikan memengaruhi efektivitas penerapan SAKIP. Berdasarkan uraian di atas, maka dapat dirumuskan hipotesis sebagai berikut:

$H_{2}$ : Dukungan pemerintah pusat berpengaruh terhadap efektivitas penerapan SAKIP.

\section{Pedoman Evaluasi atas Implementasi SAKIP Terhadap Efektivitas Penerapan SAKIP}

Dalam pedoman evaluasi atas implementasi SAKIP terdapat sub bab pencapaian sasaran kinerja yang tercantum dalam Renstra. Renstra merupakan suatu proses yang dilakukan organisasi untuk menentukan program dan kegiatan apa saja yang dapat mendukung ke arah perubahan yang lebih baik untuk instansi tersebut. Perencanaan strategis adalah sebuah arahan yang dapat dilakukan organisasi untuk melakukan proyeksi di masa yang akan datang. Rencana strategi mencakup dokumen yang setidaknya dibuat dalam rentang waktu lima tahun, yang berisi mengenai visi, misi, tujuan, sasaran, strategi dalam organisaisi. Orga- 
nisasi yang sukses dalam pencapaian tujuan organisasinya akan mendemostrasikan fleksibilitas dalam pemilihan keputusan-keputusan rencana startegis (Rudd, Greenley, Beatson, and Lings, 2008 dalam Nusantoro dan Subiyantoro, 2009).

Dalam hasil penelitian Utomo (2015) menunjukkan bahwa komponen-komponen SAKIP pada pelaksanaan SAKIP di Kota Tarakan memiliki hubungan yang logis berdasarkan konsep logika, dengan maksud dapat dijelaskan terdapat keterkaitan antara komponen mulai dari sumber daya yang dialokasikan, kegiatan yang dilaksanakan, serta dampak yang ingin dirasakan, dan hasil penelitian Sari (2015) menunjukkan hasil bahwa komponen SAKIP Kabupaten Sleman sebagian besar menunjukkan kesesuaian informasi pada dokumen perencanaan serta dokumen pelaporan. Namun pada penelitian Widodo (2010) yang berjudul Policy Implementation of Governmental Institution Performance Accountability (AKIP) that is Embodied in the Report of Governmental Institution Accountability (LAKIP), menyatakan bahwa indikator-indikator yang terdapat dalam LAKIP tidak berpengaruh dalam menilai atau mengevaluasi keberhasilan dari program dan kebijakan yang pemerintah susun. Berdasarkan uraian di atas, maka dapat dirumuskan hipotesis sebagai berikut:

$H_{3}:$ Pedoman evaluasi atas implementasi SAKIP berpengaruh terhadap efektivitas penerapan SAKIP.

\section{Kualitas dan Kuantitas Sumber Daya Manusia Terhadap Efektivitas Penerapan SAKIP}

Sumber daya manusia merupakan faktor yang sangat penting dalam keberhasilan suatu organisasi, semakin tinggi kualitas sumber daya manusia maka akan semakin tinggi kinerja yang akan dihasilkan dalam mencapai tujuan organisasi dan ketersediaan atau jumlah aparatur sipil negara untuk satu tugas pokok dan fungsi harus sesuai dengan beban kerjanya. Hal ini diperlukan pengelolaan sumber daya manusia secara tepat sesuai dengan beban kerja yang ada. Menurut Umar (1999: 42) perencanaan sumber daya manusia adalah melakukan cara-cara tertentu dalam menetapkan tenaga kerja baik secara kualitas maupun kuantitas yang dibutuhkan pada periode tertentu.

Dalam hasil penelitian Simanjuntak (2013) bahwa sumber daya manusia berpengaruh signifikan terhadap kinerja, sumber daya manusia merupakan hal terpenting untuk menentukan berhasil tidaknya suatu organisasi dalam mencapai tujuannya. Berdasarkan uraian di atas, maka dapat dirumuskan hipotesis sebagai berikut:

$H_{4}:$ Kualitas dan kuantitas sumber daya manusia berpengaruh terhadap efektivitas penerapan SAKIP.

\section{METODE PENELITIAN}

Penelitian ini dilakukan untuk mengetahui dan membuktikan komitmen satuan kerja, dukungan pemerintah pusat, pedoman evaluasi atas implementasi SAKIP, dan kualitas dan kuantitas sumber daya manusia sebagai variabel independen terhadap efektivitas penerapan Sistem Akuntabilitas Kinerja Instansi Pemerintah (SAKIP) sebagai variabel dependen.

Populasi dalam penelitian ini yaitu pegawai di Satuan Kerja Kementerian Pekerjaan Umum Direktorat Jenderal Cipta Karya di Provinsi Kepulauan Riau yang terdiri dari 3 (tiga) satuan kerja, yaitu: (1) Pegawai di Satuan Kerja Perencanaan dan Pengendalian Program Infrastruktur Permukiman (Randal) Provinsi Kepulauan Riau, dimana Satuan Kerja Randal sebagai koordinator wilayah yang mewakili Provinsi Kepulauan Riau yang mengoordinasikan 2 (dua) satuan kerja: (2) Pegawai di Satuan Kerja Pengembangan Kawasan Permukiman dan 
Determinan Efektivitas Penerapan... 836
Penataan Bangunan Provinsi Kepulauan Riau; (3) Pegawai di Satuan Kerja Pengembangan Air Minum dan Sanitasi Provinsi Kepulauan Riau. Penelitian ini menggunakan Nonprobability Sampling dengan sampel jenuh (sampling sensus).

Peneliti menggunakan metode sampel jenuh dikarenakan peneliti ingin mendapatkan hasil yang menyuluruh baik dari sudut pandang atasan hingga bawahan seluruh pegawai, sehingga sampel yang digunakan dalam penelitian ini berjumlah 110 (seratus sepuluh), yaitu pegawai yang melaksanakan fungsi sebagai petugas yang bertanggung jawab dalam satuan kerja. Penelitian ini menggunakan metode survei melalui penyebaran kuesioner. Responden dalam penelitian ini adalah seluruh pegawai di Satuan Kerja Kementerian Pekerjaan Umum Direktorat Jenderal Cipta Karya di Provinsi Kepulauan Riau yang berjumlah 110 responden.

\section{HASIL DAN PEMBAHASAN}

Dalam penelitian ini dijelaskan hasil uji validitas dan reliabilitas indikator konstruk pada kuesioner penelitian untuk memastikan bahwa indikator konstruk yang digunakan telah memenuhi kriteria valid dan reliabel, sehingga data yang dihasilkan akurat.

\section{Uji Validitas}

Tabel 1

\begin{tabular}{cc}
\hline Sig. & 0,000 \\
\hline KMO & 0,719 \\
\hline
\end{tabular}

Tabel 2. Measures of Sampling Adequacy Per Item Kuesioner

\begin{tabular}{|c|c|c|c|}
\hline Item Pertanyaan & Nilai MSA & 0,5 & Keterangan \\
\hline \multicolumn{4}{|c|}{ Variabel Komitmen Satuan Kerja (X1) } \\
\hline KSK1 & 0,675 & \multirow[t]{2}{*}{0,5} & Valid \\
\hline KSK2 & 0,745 & & Valid \\
\hline \multicolumn{4}{|c|}{ Variabel Dukungan Pemerintah Pusat (X2) } \\
\hline DPP1 & 0,554 & \multirow{3}{*}{0,5} & Valid \\
\hline DPP2 & 0,739 & & Valid \\
\hline DPP3 & 0,688 & & Valid \\
\hline \multicolumn{4}{|c|}{ Variabel Pedoman Evaluasi dan Implementasi SAKIP (X3) } \\
\hline PE1 & 0,721 & \multirow{6}{*}{0,5} & Valid \\
\hline PE2 & 0,662 & & Valid \\
\hline PE3 & 0,692 & & Valid \\
\hline $\mathrm{PE} 4$ & 0,772 & & Valid \\
\hline PE5 & 0,774 & & Valid \\
\hline PE6 & 0,760 & & Valid \\
\hline \multicolumn{4}{|c|}{ Variabel Kualitas dan Kuantitas Sumber Daya Manusia (X4) } \\
\hline KKSDM1 & 0,565 & \multirow{4}{*}{0,5} & Valid \\
\hline KKSDM2 & 0,837 & & Valid \\
\hline KKSDM3 & 0,775 & & Valid \\
\hline KKSDM4 & 0,768 & & Valid \\
\hline \multicolumn{4}{|c|}{ Variabel Efektivitas Penerapan SAKIP(Y) } \\
\hline EPS1 & 0,693 & \multirow{7}{*}{0,5} & Valid \\
\hline EPS2 & 0,581 & & Valid \\
\hline EPS3 & 0,577 & & Valid \\
\hline EPS4 & 0,661 & & Valid \\
\hline EPS5 & 0,842 & & Valid \\
\hline EPS6 & 0,687 & & Valid \\
\hline EPS7 & 0,767 & & Valid \\
\hline
\end{tabular}


Hasil uji validitas dan seluruh indikator konstruk memiliki nilai K-M-O MSA $>0,5$, sehingga indikator konstruk dalam kuesioner dinyatakan valid. Uji reliabilitas dilakukan untuk menguji keandalan indikator konstruk yang digunakan pada kuesioner penelitian dalam mengukur variabel penelitian dengan menghasilkan pengukuran yang konsisten. Teknik yang digunakan adalah uji Cronbachs Alpha. hasil uji realibilitas menghasilkan angka Cronbach Alpha yaitu variabel komitmen satuan kerja sebesar 0,606 (reliabilitas tinggi), variabel dukungan pemerintah pusat sebesar 0,437 (reliabilitas sedang), variabel pedoman evaluasi atas implementasi SAKIP sebesar 0,721 (reliabilitas tinggi), variabel kualitas dan kuantitas sumber daya manusia sebesar 0,518 (reliabilitas sedang), dan variabel efektivitas penerapan SAKIP sebesar 0,734 (reliabilitas tinggi) berdasarkan hasil ini dapat disimpulkan item pertanyaan kuesioner sudah memiliki reliabilitas yang baik.

\section{Demografi Responden}

\begin{tabular}{|l|l|c|c|}
\hline \multirow{2}{*}{ Dasar Klasifikasi } & \multicolumn{1}{|c|}{ Subklasifikasi } & $\begin{array}{c}\text { Jumlah } \\
\text { Responden }\end{array}$ & Presentase \\
\hline \multirow{3}{*}{ Jenis Kelamin } & Laki-laki & 42 & $51,22 \%$ \\
\cline { 2 - 4 } $\begin{array}{l}\text { Tendidikan } \\
\text { Terakhir }\end{array}$ & Perempuan & 40 & $48,78 \%$ \\
\cline { 2 - 4 } & Diploma & 12 & $14,63 \%$ \\
\cline { 2 - 4 } & Sarjana & 52 & $9,76 \%$ \\
\cline { 2 - 4 } & Pascasarjana & 10 & $63,41 \%$ \\
\hline \multirow{5}{*}{ Jabatan } & Kepala Satuan Kerja & 4 & $12,20 \%$ \\
\cline { 2 - 4 } & $\begin{array}{l}\text { Pejabat Pembuat } \\
\text { Komitmen (PPK) }\end{array}$ & 2 & $2,48 \%$ \\
\cline { 2 - 4 } & $\begin{array}{l}\text { Pejabat Surat Perintah } \\
\text { Membayar (SPM) }\end{array}$ & 3 & $3,66 \%$ \\
\cline { 2 - 4 } & Bendahara & 6 & $7,32 \%$ \\
\cline { 2 - 4 } & Pelaksana & 67 & $81,71 \%$ \\
\hline \multirow{5}{*}{ Masa Kerja } & 2 s/d 5 tahun & 28 & $34,15 \%$ \\
\cline { 2 - 4 } & $>5$ s/d 10 tahun & 37 & $20,73 \%$ \\
\cline { 2 - 4 } & $>10$ tahun & 17 & \\
\hline
\end{tabular}

Berdasarkan tabel 3 responden laki-laki lebih banyak yaitu sebesar 51,22\% dibandingkan dengan responden perempuan sebesar 48,78\%. Tingkat pendidikan terakhir responden yang paling tinggi adalah sarjana sebesar $63,41 \%$ kemudian tingkat yang paling rendah adalah tingkat diploma sebesar 9,76\%. Proporsi terbesar responden berdasarkan masa kerja adalah $>5$ sampai dengan 10 tahun yaitu sebesar $45,12 \%$, responden dengan masa kerja 2 sampai dengan 5 tahun sebesar $34,15 \%$, dan responden dengan masa kerja > 10 tahun sebesar 20,73\%.

\section{Karakteristik Jawaban Responden}

Data statistik deskriptif ditampilkan pada tabel 4 yang memberikan gambaran mengenai nilai minimum, nilai maksimum, nilai rata-rata dan deviasi standar yang digunakan dalam penelitian. Skala likert yang digunakan dalam penelitian ini adalah (1) sangat tidak setuju, (2) tidak setuju, (3) netral, (4) setuju, dan (5) sangat setuju. Pengukuran statistik deskriptif pada penelitian ini dilakukan dengan menggunakan program Statistical SPSS versi 20. Berikut disajikan deskripsi dari jawaban responden:
Tabel 3.

Karakteristik

Demografi

Responden 


\section{Determinan Efektivitas Penerapan...}

\section{8}

Tabel 4. Hasil Uji Statistika Deskriptif

Tabel 5. Hasil Uji Normalitas dangan Uji KolmogorovSmirnov

\begin{tabular}{|c|c|c|c|c|c|}
\hline Item Pertanyaa & $\mathbf{N}$ & Minimum & Maksimum & Rata-rata & $\begin{array}{l}\text { Deviasi } \\
\text { Standar }\end{array}$ \\
\hline \multicolumn{6}{|c|}{ Variabel Komitmen Satuan Kerja (X1) } \\
\hline KSK1 & 82 & 1 & 5 & \multirow{2}{*}{4,18} & \multirow[t]{2}{*}{0,683} \\
\hline KSK2 & 82 & 2 & 5 & & \\
\hline \multicolumn{6}{|c|}{ Variabel Dukungan Pemerintah Pusat (X2) } \\
\hline DPP1 & 82 & 2 & 5 & \multirow{3}{*}{3,79} & \multirow{3}{*}{0,808} \\
\hline DPP2 & 82 & 3 & 5 & & \\
\hline DPP3 & 82 & 1 & 5 & & \\
\hline \multicolumn{6}{|c|}{ Variabel Pedoman Evaluasi atas Implementasi SAKIP (X3) } \\
\hline PE1 & 82 & 2 & 5 & \multirow{6}{*}{4,04} & \multirow{6}{*}{0,644} \\
\hline PE2 & 82 & 3 & 5 & & \\
\hline PE3 & 82 & 3 & 5 & & \\
\hline PE4 & 82 & 2 & 5 & & \\
\hline PE5 & 82 & 1 & 5 & & \\
\hline PE6 & 82 & 1 & 5 & & \\
\hline \multicolumn{6}{|c|}{ Variabel Kualitas dan Kuantitas Sumber Daya Manusia (X4) } \\
\hline KKSDM1 & 82 & 3 & 5 & \multirow{4}{*}{4,11} & \multirow{4}{*}{0,623} \\
\hline KKSDM2 & 82 & 1 & 5 & & \\
\hline KKSDM3 & 82 & 1 & 5 & & \\
\hline KKSDM4 & 82 & 2 & 5 & & \\
\hline \multicolumn{6}{|c|}{ Variabel Efektivitas Penerapan SAKIP (Y) } \\
\hline EPS1 & 82 & 1 & 5 & \multirow{7}{*}{3,86} & \multirow{7}{*}{0,630} \\
\hline EPS2 & 82 & 1 & 5 & & \\
\hline EPS3 & 82 & 2 & 5 & & \\
\hline EPS4 & 82 & 2 & 5 & & \\
\hline EPS5 & 82 & 2 & 5 & & \\
\hline EPS6 & 82 & 2 & 5 & & \\
\hline EPS7 & 82 & 3 & 5 & & \\
\hline
\end{tabular}

\section{Hasil Uji Asumsi Klasik}

\section{Hasil Uji Normalitas}

Uji normalitas bertujuan menguji apakah dalam model regresi atau nilai residual, variabel pengganggu atau residual memiliki distribusi normal atau tidak. Kriteria Kolmogorov-Smirnov > 0,05. Hasil penelitian ini dapat dilihat dari nilai Asymp. Sig (2-tailed) adalah 0,949 >0,05, dapat disimpulkan bahwa data berdistribusi normal.

\begin{tabular}{lc}
\hline & Standardized Residual \\
\hline Kolmogorov-Smirnov & 0,949
\end{tabular}

Berdasarkan gambar 2 dapat dilihat bahwa titik-titik berada pada pola distribusi normal yaitu disekitar garis diagonal dan penyebarannya mengikuti arah garis diagonal. Dengan demikian dapat dinyatakan bahwa penyebaran data mendekati normal atau memenuhi kriteria normalitas. 


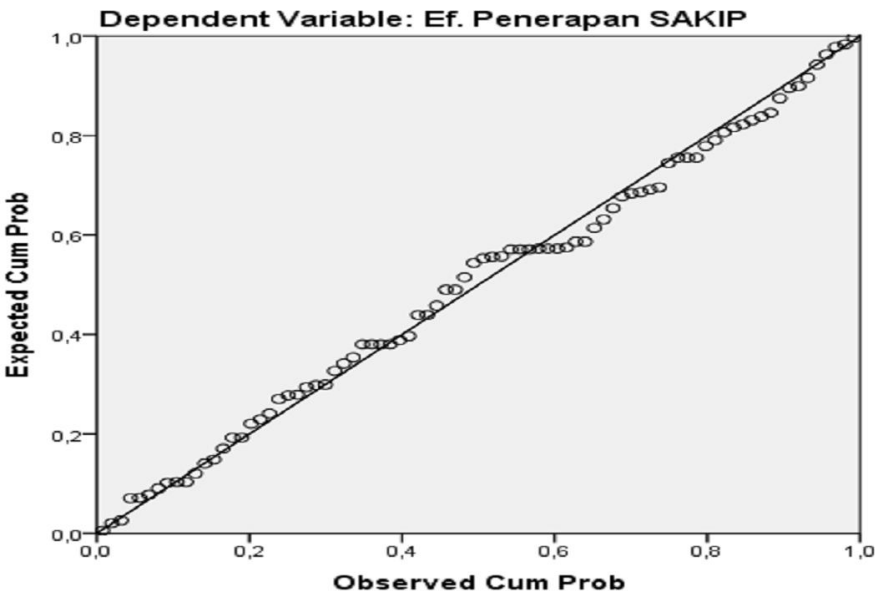

\section{Hasil Uji Multikolinearitas}

Uji multikolinearitas digunakan untuk menguji apakah ada korelasi antara variabel independen. Berdasarkan hasil pengujian pada tabel 6. dengan kriteria nilai $\mathrm{VIF}<10$, menghasilkan nilai untuk komitmen satuan kerja sebesar 1,490, dukungan pmerintah pusat sebesar 1,208, pedoman evaluasi atas implementasi SAKIP sebesar 1,866, dan kualitas dan kuantitas sumber daya manusia sebesar 1,569 yang berarti model regresi tersebut tidak terdapat multikolinieritas antar variabel independen.

\begin{tabular}{lccc}
\hline \multicolumn{1}{c}{ Variabel } & Nilai VIF & $<10$ & Keterangan \\
\hline Komitmen Satuan Kerja & 1,490 & & Bebas Multikolinearitas \\
$\begin{array}{l}\text { Dukungan Pemerintah Pusat } \\
\text { Pedoman Evaluasi atas Implementasi }\end{array}$ & 1,208 & & Bebas Multikolinearitas \\
$\begin{array}{l}\text { SAKIP } \\
\text { Kualitas dan Kuantitas Sumber Daya }\end{array}$ & 1,569 & & Bebas Multikolinearitas \\
Manusia & & & Bebas Multikolinearitas \\
\hline
\end{tabular}

Gambar 2.

Normal Probability Plot

Tabel 6. Hasil Uji Multikolinearitas

\section{Hasil Uji Heteroskedastisitas}

Heteroskedastisitas bertujuan menguji apakah dalam model regresi terjadi ketidaksamaan variance dari residual satu pengamatan ke pengamatan yang lain jika variance dari residual satu pengamatan ke pengamatan lain tetap, maka disebut homokedastisitas dan jika berbeda disebut heteroskedastisitas. Berdasarkan hasil grafik scatterplot pada gambar 3 dapat dilihat bahwa tidak ada pola yang jelas, serta titik-titik menyebar di atas dan di bawah 0 pada sumbu Y, maka dapat disimpulkan tidak terjadi heteroskedastisitas pada model regresi layak dipakai untuk memprediksi efektivitas penerapan SAKIP berdasarkan masukan variabel independennya yaitu komitmen satuan kerja, dukungan pemerintah pusat, pedoman evaluasi atas implementasi SAKIP, dan kualitas dan kuantitas sumber daya manusia. 


\section{Determinan Efektivitas \\ Penerapan...}

Gambar 3 Grafik Scatterplot

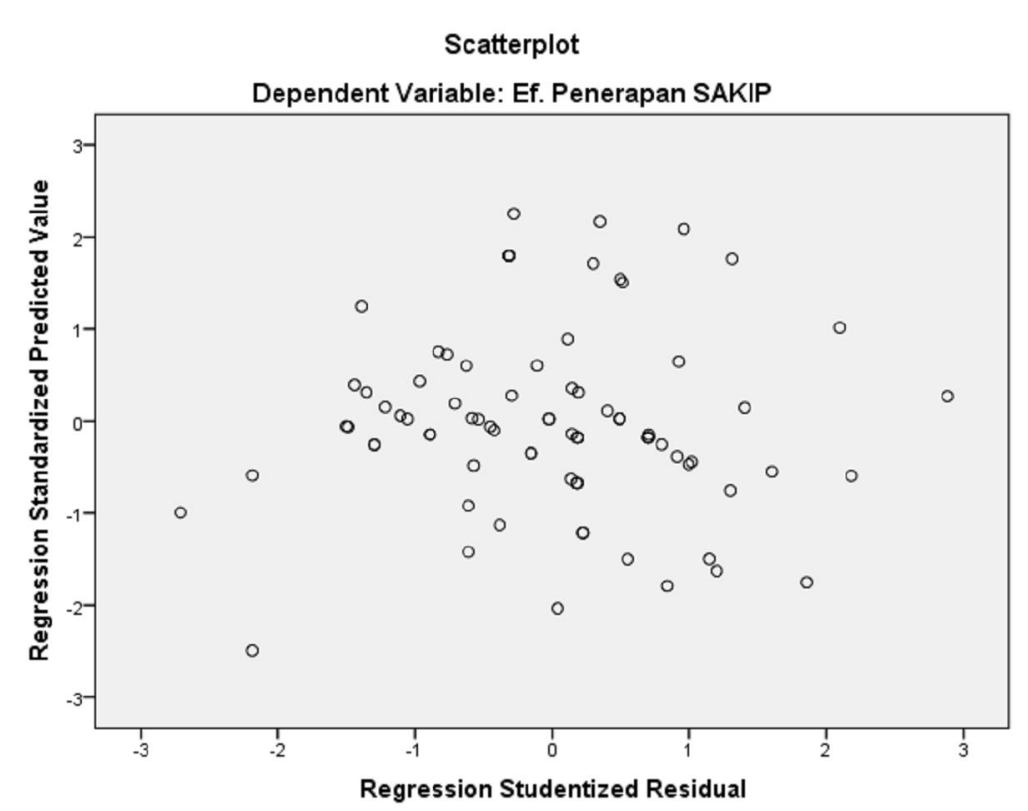

\section{Hasil Analisis Data}

Dari nilai unstandardized coefficient (â) yang dihasilkan analisis regresi diperoleh persamaan regresi sebagai berikut:

$\mathrm{Y}=0,691+0,165 X_{1}+0,073 X_{2}+0,188 X_{3}+0,352 X_{4}+\mathrm{e}$

Nilai konstanta sebesar 0,691, artinya jika jika nilai variabel independen sama dengan nol, maka efektivitas penerapan SAKIP (Y) sama dengan 0,691. Nilai koefisien regresi komitmen (X1) satuan kerja sebesar 0,165, yang artinya jika komitmen satuan kerja ditingkatkan maka akan meningkatkan efektivitas penerapan SAKIP (Y) sebesar 0,165. Nilai koefisen dukungan pemerintah pusat (X2) sebesar 0,073, yang artinya jika dukungan pemerintah pusat ditingkatkan maka akan meningkatkan efektivitas penerapan SAKIP (Y) sebesar 0,073. Nilai koefisien pedoman evaluasi atas implementasi SAKIP (X3) sebesar 0,188, yang artinya jika pedoman evaluasi atas implementasi SAKIP ditingkatkan maka akan meningkatkan efektivitas penerapan SAKIP (Y) sebesar 0,188. Nilai koefisien kualitas dan kuantitas sumber daya manusia (X4) sebesar 0,352, yang artinya jika kualitas dan kuantitas sumber daya manusia ditingkatkan maka akan meningkatkan efektivitas penerapan SAKIP (Y) sebesar 0,352, dan standar error (e) menunjukkan tingkat kesalahan pengganggu.

\section{Hasil Uji Koefisien Determinan (Adjusted $R^{2}$ )}

Determinan $\left(R^{2}\right)$ atau $\mathrm{R}$ - Square digunakan untuk melihat berapa besar variabel independen mampu menjelaskan variabel dependen. Nilai koefisien determinasi (Adjusted) penelitian ini sebesar 0,498 (lampiran 5 (lima)), yang berarti bahwa variabel dependen (efektivitas penerapan SAKIP) mampu dijelaskan oleh variabel independen (komitmen satuan kerja, dukungan pemerintah pusat, pedoman evaluasi atas implementasi SAKIP, dan kualitas dan kuantitas sumber daya manusia) sebesar 49,8\% dan selebihnya 50,2\% $(100 \%-49,8 \%=50,2 \%)$ dijelas ${ }^{-}$ kan oleh faktor-faktor penentu lain yang tidak diikut sertakan dalam penelitian ini.

\section{Hasil Uji Hipotesis}

Penelitian ini dalam pengujian hipotesis menggunakan uji t dalam regresi linear berganda. Uji t digunakan untuk melihat pengaruh dari komitmen satuan 

dan kualitas dan kuantitas sumber daya manusia terhadap efektivitas penerapan SAKIP. Hasil uji hipotesis ini dapat di lihat pada tabel 7.

\begin{tabular}{lcc}
\hline \multicolumn{1}{c}{ Variabel } & Sig. & Keterangan \\
\hline Komitmen Satuan Kerja & 0,014 & Hipotesis diterima \\
Dukungan Pemerintah Pusat & 0,226 & Hipotesis ditolak \\
Pedoman Evaluasi atas Implementasi SAKIP & 0,056 & Hipotesis ditolak \\
Kualitas dan Kuantitas Sumber Daya Manusia & 0,001 & Hipotesis diterima \\
\hline
\end{tabular}

\section{KESIMPULAN}

Berdasarkan hasil analisis data dan pengujian hipotesis yang telah diuraikan pada bab sebelumnya, maka peneliti mengambil kesimpulan mengenai pengaruh komitmen satuan kerja, dukungan pemerintah pusat, pedoman evaluasi atas implementasi SAKIP, dan kualitas dan kuantitas sumber daya manusia terhadap efektivitas penerapan SAKIP, sebagai berikut:

1. Hipotesis 1. Variabel Komitmen Satuan Kerja (X1)

Berdasarkan tabel 5.9 H1 diterima, artinya komitmen satuan kerja (X1) berpengaruh secara signifikan terhadap efektivitas penerapan SAKIP di Satuan Kerja Direktorat Jenderal Cipta Karya Kementerian Pekerjaan Umum Provinsi Kepulauan Riau. Hasil empiris penelitian ini menunjukkan dengan adanya komitmen dalam keterlibatan antara karyawan (partisipasi pengambilan keputusan, team work, komunikasi) maka dapat meningkatkan hasil kinerja untuk tercapainya nilai dan sasaran organisasi yang diinginkan. Pelaksanaan SAKIP di lingkungan Satuan Kerja Direktorat Jenderal Cipta Karya Kementerian Pekerjaan Umum Provinsi Kepulauan Riau dipengaruhi oleh isomorfisma normatif yang bersifat kuat, yaitu mengutamakan pada profesionalitas. Isomorfisma normatif merupakan bentuk perjuangan dari anggota organisasi untuk menentukan kondisi dan metoda yang digunakan dalam kegiatan organisasi mereka, sehingga dapat mengontrol "produksi" dan melegitimasi otonomi kegiatan dalam organisasi (Larson, 1977; Collins, 1979; Dimaggio dan Powell 1983 dalam Sofyani dan Akbar, 2013).

Institusionalisasi merupakan proses organisasi untuk menetapkan suatu karakter yang ditentukan oleh komitmen organisasi dengan prinsip dan nilainilai (Selznick, 1992 dalam Dacin, 2002). Hasil penelitian yang mendukung mengenai komitmen satuan kerja diantaranya Shadur, dkk (1999), Prihantoro (2012), dan Kusuma (2013) yang hasil penelitiannya menunjukkan komitmen organisasi berpengaruh positif, artinya dengan adanya komitmen organisasi yang tinggi terhadap organisasi maka semakin tinggi pula pencapaian nilainilai dan sasaran organisasi, hal ini disebabkan dengan adanya komitmen organisasi yang kuat dari setiap pegawai akan menyebabkan pegawai tersebut berusaha keras untuk pencapaian tujuan organisasi.

2. Hipotesis 2. Variabel Dukungan Pemerintah Pusat (X2)

Berdasarkan tabel $5.9 \mathrm{H} 2$ ditolak, dukungan pemerintah pusat (X2) tidak berpengaruh terhadap efektivitas penerapan SAKIP. Hasil penelitian ini memberikan kesimpulan bahwa terdapat isomorfisma normatif yang bersifat lemah pada Satuan Kerja Direktorat Jenderal Cipta Karya Kementerian Pekerjaan Umum Provinsi Kepulauan Riau, dimana tingkat profesionalisasi pemerintah pusat terhadap satuan kerja di daerah akan mempengaruhi respon terkait penerapan SAKIP. Hal ini menyebabkan kurangnya partisipasi dari pemerintah pusat untuk membantu satuan kerja di daerah dalam pembinaan, koordinasi, pemantauan, dan supervisi pelaksanaan evaluasi atas implementasi SAKIP dalam melaksanakan evaluasi atas implementasi SAKIP di satuan kerja Direktorat Jenderal Cipta Karya Kementerian Pekerjaan Umum Provinsi Kepulauan Riau, sehingga SAKIP belum efektif dalam penerapannya. 


\section{Determinan Efektivitas Penerapan...}

Hal lain yang juga berpengaruh adalah sistem pengawasan oleh instansi pengawas (BPKP) belum berjalan dengan optimal.

Hasil penelitian ini sama dengan penelitian Yusrianti dan Safitri (2015), yang hasilnya menunjukkan bahwa terdapat 13 SKPD pada klasifikasi kurang baik pada evaluasi implementasi SAKIP sehingga diperlukannya asistensi dalam penyusunan LAKIP oleh BPKP, serta lemahnya fungsi asistensi dari pihak BPKP menyebabkan tidak adanya reviu mengenai LAKIP sehinga tidak dapat mendeteksi LAKIP SKPD yang belum sesuai dengan pedoman LAN. Namun hasil penelitian ini bertentangan dengan hasil penelitian Nusantoro dan Subiyantoro (2009) yang menunjukkan bahwa dukungan pemerintah pusat dapat dijadikan faktor dalam meningkatkan efektivitas penerapan SAKIP. Bila dikaitkan dengan hasil pengelolaan data statistika deskriptif pada penelitian ini dengan penelitian Nusantoro dan Subiyantoro (2009) dikarenakan rendahnya faktor efektivitas penerapan SAKIP dengan hubungan pemerintah pusat, tercermin dari banyaknya responden yang menjawab tidak/ kurang setuju dengan adanya pengawasan dan pemeriksaan LAKIP oleh BPKP.

3. Hipotesis 3. Variabel Pedoman Evaluasi atas Implementasi SAKIP (X3)

Berdasarkan tabel 5.9 H3 ditolak, artinya pedoman evaluasi atas implementasi SAKIP tidak berpengaruh terhadap efektivitas penerapan SAKIP. Hal ini disebabkan oleh Renstra yang sudah disusun Pemerintah Pusat belum digunakan secara optimal sebagai acuan oleh satuan kerja dalam menyusun perencanaan kinerja, melaksanakan dan mengendalikan program kegiatan pembangunan sehingga evaluasi atas implementasi SAKIP yang mengacu pada Peraturan Menteri No. 12 Tahun 2015 belum efektif. Sehingga terdapat tekanan (isomorfisma koersif) yang dialami Satuan Kerja Direktorat Jenderal Cipta Karya Kementerian Pekerjaan Umum Provinsi Kepulauan Riau. Berdasarkan isomorfisma koersif yang berada dalan teori institusional, kekuatan koersif adalah tekanan eksternal yang diberikan pemerintah, peraturan atau lembaga lain untuk mengadopsi suatu sistem (Ashworth, 2009).

Hal ini juga diperkuat dengan fakta di lapangan bahwa pegawai belum memahami dengan baik mengenai pedoman evaluasi atas implementasi SAKIP, yang mayoritas satuan kerja menyusun dan melaporkan LAKIP hanya sebatas kewajiban pertanggungjawaban realisasi keuangan saja tanpa melihat outcome dari program kegiatan yang dihasilkan dapat memberikan kebermanfaatan atau tidak. Hasil empiris mengenai pedoman evaluasi atas implementasi SAKIP ini sependapat dengan hasil penelitian Acintya dan Putri (2015) menunjukkan bahwa implementasi SAKIP tidak memiliki pengaruh pada kinerja pemerintah Kota Denpasar, dikarenakan kurangnya pemahaman aparat dan pejabat di masing-masing SKPD terhadap SAKIP.

4. Hipotesis 4. Variabel Kualitas dan Kuantitas Sumber Daya Manusia (X4) Berdasarkan tabel $5.9 \mathrm{H} 4$ diterima, artinya kualitas dan kuantitas sumber daya manusia berpengaruh secara signifikan terhadap efektivitas penerapan SAKIP di Satuan Kerja Direktorat Jenderal Cipta Karya Kementerian Pekerjaan Umum Provinsi Kepulauan Riau. Hasil penelitian ini membuktikan bahwa sumber daya manusia merupakan komponen penting dalam pelaksanaan SAKIP karena dalam Peraturan Menteri PAN dan RB No. 12 Tahun 2015 menyatakan untuk melaksanakan evaluasi atas implementasi SAKIP dengan baik maka diperlukan kualitas dan kuantitas sumber daya manusia yang tepat agar pedoman evaluasi atas implementasi SAKIP dapat dijadikan panduan bagi evaluator. Dalam Satuan Kerja Direktorat Jenderal Cipta Karya Kementerian Pekerjaan Umum Provinsi Kepulauan Riau terdapat isomorfisma normatif.

Isomorfisma normatif dalam satuan kerja ini berasal dari pendidikan dan standar profesionalisme yang sifatnya kuat. Manajemen merespon untuk isomorfisma normatif ini dengan cara menata uraian jabatan sesuai dengan 
kemampuan akademik atau pendidikan dengan tujuan agar penerapan SAKIP berjalan dengan efektif, dikarenakan SAKIP dibuat bertujuan untuk mempermudah pekerjaan sehingga dapat mendukung pencapaian tujuan dan sasaran satuan kerja instansi pemerintah. Hasil empiris ini memberikan bukti kuat hasil penelitian Simanjuntak (2013) bahwa sumber daya manusia ber_pengaruh signifikan terhadap kinerja, sumber daya manusia merupakan hal terpenting untuk menentukan berhasil tidaknya suatu organisasi dalam mencapai tujuannya.

Hasil pengujian menghasilkan nilai koefisien determinasi (Adjusted) penelitian ini sebesar 0,498 (lampiran 5 (lima)), yang berarti bahwa variabel dependen (efektivitas penerapan SAKIP) mampu dijelaskan oleh variabel independen (komitmen satuan kerja, dukungan pemerintah pusat, pedoman evaluasi atas implementasi SAKIP, dan kualitas dan kuantitas sumber daya manusia) sebesar $49,8 \%$ dan selebihnya $50,2 \%(100 \%-49,8 \%=50,2 \%)$ dapat dijelaskan oleh faktor-faktor lain yang tidak diikut sertakan dalam penelitian ini.

\section{DAFTAR PUSTAKA}

Acintya, I. G. A. A. D., dan Putri I. G. A. M. A. D. 2015. Kinerja Pemerintah Kota Denpasar Dalam Implementasi SAKIP dan Penerapan Good Governance. EJurnal Akuntansi Universitas Udayana. ISSN: 2302-8556. Vol. 12. No. 2. Pg. 233-248.

Arikunto, S. 2006. Prosedur Penelitian Suatu Pendekatan Praktik. Rineka Cipta. Jakarta.

Ashworth, R., Boyne, G., dan Delbridge, R. 2009. Escape from the Iron Cage? Organizational Change and Isomorphic Pressures in the Public Sector. Journal of Public Administration Research and Theory. JPART 19. Pg. 165-187.

Auditya, L., Husaini., dan Lismawati. 2013. Analisis Pengaruh Akuntabilitas Dan Transparansi Pengelolaan Keuangan Daerah Terhadap Kinerja Pemerintah Daerah. Jurnal Fairness. ISSN 2303-0348. Vol. 3. No. 1. Maret 2013. Pg. 2141.

Badruzaman, J., dan Chairunnisa, I. 2011. Pengaruh Implementasi Sistem Akuntabilitas Kinerja Instansi Pemerintah (SAKIP) Terhadap Penerapan Good Governance. Jurnal Akuntansi dan Bisnis AUDI. Vol. 7. No. 1. Pg. 57-70.

Basri, R. 2013. Analisis Penyusunan Anggaran Dan Laporan Realisasi Anggaran Pada BPM-PD Provinsi Sulawesi Utara. Jurnal EMBA. ISSN 2303-1174. Vol. 1. No. 4. Desember 2013. Pg. 202-212

Badan Pengawasan Keuangan dan Pembangunan. 2011. Akuntabilitas Instansi Pemerintah (Revisi Keenam). Pusat Pendidikan dan Pelatihan Pengawasan BPKP. Bogor.

Dacin, M. T., Goodstein, J., dan Scott, W. R. 2002. Institutional Theory and Institutional Change: Introduction to the Special Research Forum. Academy of Management Journal. Vol. 45. No. 1. Pg. 45-57.

Dimaggio, P., dan Powell, W. W. 1983. The Iron Cage Revisited: Institutional Isomorphism and Collective Rationality in Organizational Fields. American Sociological Review. Vol. 48. No. 2. Pg. 147-160.

Dwipayana, A. 2003. Membangun Good Governance di Desa. IRE Press. Yogyakarta.

Frumkin, P dan Galaskiewicz, J. 2004. Institutional Isomorphism and Public Sector Organizations. Journal of Public Administration Research and Theory. 14(3). Pg. 283-307.

Ghozali, I. 2011. Aplikasi Analisis Multivariate Dengan Program IBM SPSS 19 (edisi kelima). Badan Penerbit Universitas Diponegoro. Semarang. 
Determinan Efektivitas Penerapan...
Ghozali, I. 2012. Aplikasi Analisis Multivariate dengan Program IBM SPSS 20. Badan Penerbit Universitas Diponegoro. Semarang.

Hair, J. F., Black, W. C., Babin, B. J. Dan Anderson, R. E. 2010. Multivariate Data Analysis: A Global Perspective (Vol. 7th). Pearson Education. United States of America.

Halim, A., dan Kusufi, M. S. 2013. Akuntansi Sektor Publik: Teori, Konsep, dan Aplikasi. Salemba Empat. Jakarta.

Harun. 2009. Reformasi Akuntansi dan Manajemen Sektor Publik di Indonesia. Salemba Empat. Jakarta.

Hasibuan, M. S. P. 2008. Manajemen Sumber Daya Manusia, edisi Revisi. Bumi Aksara. Jakarta.

Hidayat, N. 2014. Penerapan Asas-asas Umum Tata Kelola Pemerintahan Yang Baik Dalam Mewujudkan Visi Dan Misi Pemerintah Kota Samarinda. Jurnal Al Ahkam Stain Palopo. Vol. IV. No. 2. Agustus 2014. Pg. 47-52.

Jun, K. N. Dan C. Weare. 2010. Institutional Motivations in the Adoption of Innovations: The Case of E-Government. Journal of Public Administration Research and Theory. Vol. 21. Issue 3. Juli 2011. Pg. 61-76.

Kencana, I. S. 1998. Manajemen Pemerintahan. PT. Pertija. Jakarta.

Ketetapan MPR Nomor IV/ MPR/ 1998 Tentang Penyelenggaraan Negara Yang Bersih dan Bebas dari Korupsi, Kolusi dan Nepotisme.

Kusuma, I. G. E. A. 2013. Pengaruh Kejelasan Sasaran Anggaran, Komitmen Organisasi Dan Ketidakpastian Lingkungan Pada Ketepatan Anggaran (Studi Empiris Di SKPD Pemerintah Provinsi Bali. Tesis. Universitas Udayana. Denpasar.

Laporan Akuntabilitas Kinerja Instansi Pemerintah (LAKIP) Satuan Kerja Pengembangan Air Minum dan Sanitasi Provinsi Kepulauan Riau. Tahun Anggaran 2015.

Laporan Akuntabilitas Kinerja Instansi Pemerintah (LAKIP) Satuan Kerja Pengembangan Kawasan Permukiman dan Penataan bangunan Provinsi Kepulauan Riau. Tahun Anggaran 2015.

Laporan Akuntabilitas Kinerja Instansi Pemerintah (LAKIP) Satuan Kerja Perencanaan dan Pengendalian Program Infrastruktur Permukiman Provinsi Kepulauan Riau. Tahun Anggaran 2015.

Lembaga Administrasi Negara dan BPKP. 2000. Akuntabilitas dan Good Governance, Modul Sosialisasi Sistem Akuntabilitas Kinerja Instansi Pemerintah. LAN-RI. Jakarta.

Lembaga Administrasi Negara Republik Indonesia. 2003. Perbaikan Pedoman Penyusunan Pelaporan Akuntabilitas Kinerja Instansi Pemerintah. Keputusan Kepala LAN Nomor. 239/ IX/ 6/ 8/ 2003. Jakarta.

Luthans, F. 2006. Perilaku Organisasi, Edisi Sepuluh. Andi Offset. Yogyakarta.

Mahmudi. 2005. Manajemen Kinerja Sektor Publik. Yogyakarta: Akademi Manajemen Perusahaan YKPN.

Mahsun, M. 2006. Pengukuran Kinerja Sektor Publik. Penerbit BPFE. Yogyakarta.

Mardiasmo. 2004. Akuntansi Sektor Publik (Edisi Kedua). Penerbit Andi. Yogyakarta.

Mardiasmo. 2005. Akuntansi Sektor Publik. Penerbit Andi. Yogyakarta.

Mardiasmo. 2006. Perwujudan Transparansi dan Akuntabilitas Publik Melalui Akuntansi Sektor Publik: Suatu Sarana Good Governance. Jurnal Akuntansi Pemerintah. Vol. 2. No. 1. Mei 2006. Pg. 2-4.

Mardiasmo. 2009. Akuntansi Sektor Publik. Penerbit Andi. Yogyakarta.

Meyer, J. W. dan Rowan, B. 1977. Institutionalized Organizations Formal Structure as Myth and Ceremony. The American Journal of Sociology. Vol. 83. No. 2. September 1977. Pg. 340-363. 
Mudhofar, K., dan Tahar, A. 2016. Pengaruh Desentralisasi Fiskal dan Kinerja Terhadap Akuntabilitas Pelaporan Keuangan Pemerintah Daerah di Indonesia: Efek Moderasi dari Kinerja. Jurnal Akuntansi dan Investasi. Vol. 17. No.2. Pg. 176-185.

Mustafa, Z. EQ. 2013. Mengurai Variabel Hingga Instrumentasi. Graha Ilmu. Yogyakarta.

Mondy, W., dan Noe, R. M. 1996. Human Resource Management. Prentice Hall Inc. New Jersey.

Monoarfa, H. 2012. Efektivitas dan Efisiensi Penyelenggaraan Pelayanan Publik: Suatu Tinjauan Kinerja Lembaga Pemerintahan. Jurnal Pelangi Ilmu. Vol. 5. No. 1. Edisi 2012. Pg. 1-9.

Mowday, R., Streers, R., dan Porter, L. 1979. The Measurement of Organizational Commitment. Journal of Vocational Behavior. Vol. 14. Issue. 2. Pg. 224-235.

Nawawi, H. H. 2008. Manajemen Sumber Daya Manusia. Gajah Mada University Press. Yogyakarta.

Nugroho, A. 2005. Strategi Jitu: Memilih Metode Statistik Penelitian dengan SPSS. Andi. Yogyakarta.

Nusantoro, S. A., dan Subiyantoro, H. 2009. Efektivitas Penerapan Sistem Akuntabilitas Kinerja Instansi Pemerintah (SAKIP) Di Kabupaten Tasikmalaya. Universitas Indonesia. Pg. 1-24.

Peraturan Kepala Badan Badan Meteorologi, Klimatologi dan Geofisika Nomor 1 Tahun 2013 Tentang Pedoman dan Penerapan SAKIP di Lingkungan Badan Meteorologi, Klimatologi dan Geofisika.

Peraturan Menteri Pendayagunaan Aparatur Negara dan Reformasi Birokrasi Republik Indonesia Nomor 12 Tahun 2015 Tentang Pedoman Evaluasi Atas Implementasi Sistem Akuntabilitas Kinerja Instansi Pemerintah.

Peraturan Menteri Pendayagunaan Aparatur Negara Dan Reformasi Birokrasi Republik Indonesia No. 53 Tahun 2014 tentang Petunjuk Teknis Perjanjian Kinerja, Pelaporan Kinerja dan Tata Cara Reviu Atas Laporan Kinerja Instansi Pemerintah.

Peraturan Presiden Republik Indonesia Nomor 29 Tahun 2014 Tentang Sistem Akuntabilitas Kinerja Instansi Pemerintah.

Poister, T. H., and Streib, G. 2005. Elements of Strategic Planning and Management in Municipal Government: Status After Two Decades. Public Administration Review. Vol. 65. No. 1. Januari-Februari. Pg. 45-56.

Pollanen, R. M. 2005. Performance Measurement in Municipalities Empirical Evidence in Canadian Context. The International Journal of Public Sector Management. 11(1). Pg. 4-24.

Prihantoro, A. 2012. Peningkatan Kinerja Sumber Daya Manusia Melalui Motivasi, Displin, Lingkungan Kerja, dan Komitmen (Studi Kasus Madrasah di Lingkungan Yayasan Salafiyah, Kajen, Margoyoso, Pati). Jurnal Unimus. Vol. 8. No. 2. Maret-Agustus 2012. Pg. 78-98.

Priyanto, D. 2009. 5 Jam Belajar Olah Data Dengan SPSS 17. Andi Offset. Jakarta.

Rasul, S., dkk. 2002. Perencanaan Kinerja Instansi Pemerintah. BPKP. Jakarta.

Sari, I. P. 2015. Evaluasi Implementasi Sistem Akuntabilitas Kinerja Instansi Pemerintah (Studi Pada Pemerintah Kabupaten Sleman). Tesis. Universitas Gajah Mada.

Sedarmayanti. 2004. Good Governance (Kepemerintahan Yang Baik) Bagian Kedua: Membangun Manajemen Sistem Kinerja Guna Meningkatkan Produktivitas Menuju Good Governance (Kepemerintahan Yang Baik). Mandar Maju. Bandung.

Sekaran, U. 2006. Research Methods For Business, Metodologi Penelitian Untuk Bisnis (Edisi Empat). Salemba Empat. Jakarta. 
Determinan Efektivitas Penerapan...
Shadur, M. A., Kienzle. R., dan Rodwell. J. J. 1999. The Relationship Between Organizational Climate and Employee Perceptions of Involvement The Importance of Support. Group and Organization Management Journal. 24. Pg. 479-504.

Siagian, S. P. 2000. Manajemen Sumber Daya Manusia. Penerbit Bumi Aksara. Jakarta.

Simanjuntak, M. D. 2013. Analisis Pengaruh Sumber Daya Manusia, Prasarana dan Lingkungan Kerja Terhadap Kinerja Pegawai Kopertis Wilayah-I Medan. Tesis. Universitas Sumatera Utara.

Sofyani, H., dan Akbar. R. 2013. Hubungan Faktor Internal Institusi Dan Implementasi Sistem Akuntabilitas Kinerja Instansi Pemerintah (SAKIP) Di Pemerintah Daerah. Jurnal Akuntansi dan Keuangan Indonesia. Vol. 10, No. 2. Pg. 184-205.

Sofyani, H., dan Akbar. R. 2015. Hubungan Karakteristik Pegawai Pemerintah Daerah dan Implementasi Sistem Pengukuran Kinerja: Perspektif Ismorfisma Institusional. JAAI. Vol. 19. No. 2. Pg. 153-173.

Stoner, J. A. F., 1982. Management. Prectice-Hall Inc. New Jersey.

Sudarmanto, G. R. 2005. Analisis Regresi Linier Ganda Dengan SPSS. Graha Ilmu. Yogyakarta.

Sukarno, G., dan Prasetyohardi. 2004. Analisis Pengaruh Kepuasan Kerja dan Komitmen Organisasi Terhadap Semangat Kerja Karyawan. Ventura. Vol. 7, No. 3. Desember. Pg. 186-196.

Sugiyono. 2012. Metode Penelitian Administrasi (Cetakan Ke-20). Penerbit Alfabeta. Bandung.

Suliyanto. 2011. Ekonometrika Terapa: Teori \& Aplikasi dengan SPSS. Penerbit Andi. Yogyakarta.

Suwandi., dan Indriantoro. N. 1999. Pengujian Model Turnover Pasewark dan Strawse: Studi Empiris Pada Lingkungan Akuntan Publik. Jurnal Riset Akuntansi Indonesia. Vol. 2. Pg. 173-195.

Tapinos, E., Dyson. R. G., dan Meadows. M. 2005. The Impact of Performance Measurement in Strategic Planning. International Journal of Productivity and Performance Management. Vol. 54. No. 5/6. Pg. 370-384.

Trihendradi, C. 2013. Langkah Praktis Menguasai Statistik untuk Ilmu Sosial Kesehatan Konsep dan Penerapannya Menggunakan SPSS. Penerbit Andi. Yogyakarta.

Ugboro, I. O. 2006. Organizational Commitment, Job Redesign, Employee Empowerment and Intent to Quit Among Survivors of Restructuring and Downsizing. Institute of Behavioral and Applied Management. North Carolina A\&T State University. Pg. 232-257.

Umar, H. 1999. Riset Sumber Daya Manusia Dalam Organisasi. PT. Gramedia Pustaka Utama. Jakarta.

Umar, H. 2004. Riset Pemasaran dan Perilaku Konsumen. PT. Gramedia Pustaka Utama. Jakarta.

Usman, H dan Akbar, R. P. S. 2012. Pengantar Statistika, Edisi Kedua. PT. Bumi Aksara. Jakarta.

Utomo, E. W. 2015. Evaluasi Pelaksanaan Sistem Akuntabilitas Kinerja Instansi Pemerintah (SAKIP) Dengan Pendekatan Model Logika Studi Pada Pemerintah Kota Tarakan. Tesis. Universitas Gajah Mada.

Villadsen, A. R. 2011. Structural Embeddedness of Political Top Executives as Explanation of Policy Isomorphism. Journal of Public Administration Research and Theory. 21(4). Pg. 573-599.

Widodo, J. 2010. Policy Implementation of Governmental Institution Performance Accountability (AKIP) that is Embodied in the Report of Governmental Insti- 
tution Accountability (LAKIP). Jurnal Aplikasi Manajemen. Vol. 8, No. 4, November 2010. Pg. 48.

Yamin, S., dkk. 2011. Regresi Dan Korelasi Dalam Genggaman Anda: Aplikasi Dengan Software SPSS, Eviews, MINITAB, dan STATGRAPHICS. Salemba Empat. Jakarta.

Yang, K., dan Hsieh, J. Y. 2007. Perspektive of Performance and Accountability in Public Administration, Managerial Effectiveness of Government Performance: Testing a Middle-Range Model. Public Administration Review. September/ October: 67, 5. ProQuest. Pg. 861.

Yusrianti, H., dan Safitri, R. H. 2015. Implementasi Sistem Akuntabilitas Kinerja Instansi Pemerintah (SAKIP) Pada Satuan Kerja Perangkat Daerah (SKPD) di Lingkungan Pemerintah Kota Palembang. Jurnal Manajemen dan Bisnis Sriwijaya. Vol. 13. No. 4. Pg. 545-558.

Yusrizal. 2008. Pengujian Validitas Konstruk Dengan Menggunakan Analisis Faktor. Jurnal Tabularasa PPS Unimed. Vol. 5. No. 1. Juni 2008. Pg. 73-92. 
